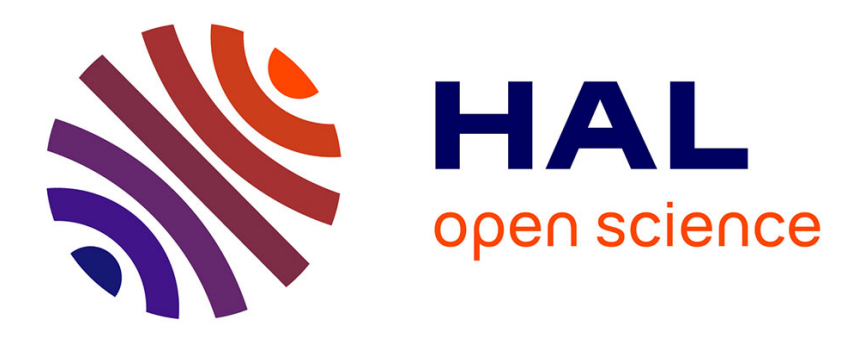

\title{
Uranium (III) precipitation in molten chloride by wet argon sparging
}

\author{
Jean-François Vigier, Annabelle Laplace, Catherine Renard, Manuel \\ Miguirditchian, Francis Abraham
}

\section{To cite this version:}

Jean-François Vigier, Annabelle Laplace, Catherine Renard, Manuel Miguirditchian, Francis Abraham. Uranium (III) precipitation in molten chloride by wet argon sparging. Journal of Nuclear Materials, 2016, 474, pp.19-27. 10.1016/j.jnucmat.2016.03.005 . cea-02386899

\section{HAL Id: cea-02386899 https://hal-cea.archives-ouvertes.fr/cea-02386899}

Submitted on 6 Jan 2020

HAL is a multi-disciplinary open access archive for the deposit and dissemination of scientific research documents, whether they are published or not. The documents may come from teaching and research institutions in France or abroad, or from public or private research centers.
L'archive ouverte pluridisciplinaire $\mathbf{H A L}$, est destinée au dépôt et à la diffusion de documents scientifiques de niveau recherche, publiés ou non, émanant des établissements d'enseignement et de recherche français ou étrangers, des laboratoires publics ou privés. 


\title{
Uranium (III) precipitation in molten chloride by wet argon sparging
}

\author{
Jean-François Vigier ${ }^{\mathrm{a}, \mathrm{b}, \text { * }}$, Annabelle Laplace ${ }^{\mathrm{a}}$, Catherine Renard ${ }^{\mathrm{b}}$, \\ Manuel Miguirditchian ${ }^{a}$, Francis Abraham ${ }^{\text {b }}$ \\ ${ }^{a}$ CEA, Nuclear Energy Division, Radiochemistry \& Processes Department, F-30207 Bagnols sur Cèze, France \\ ${ }^{\mathrm{b}}$ Unité de Catalyse et de Chimie du Solide, UCCS UMR CNRS 8181, Univ. Lille Nord de France, ENSCL-USTL, B.P. 90108, 59652 Villeneuve d'Ascq Cedex, France
}

\section{H I G H L I G H T S}

- Precipitation of Uranium (III) is quantitative in molten salt $\mathrm{LiCl}-\mathrm{CaCl}_{2}$ (30-70 mol\%).

- The salt is oxoacid with a water dissociation constant of $10^{-4.0}$ at $705^{\circ} \mathrm{C}$.

- Volatility of uranium chloride is strongly reduced in reductive conditions.

- Coprecipitation of $\mathrm{U}(\mathrm{III})$ and $\mathrm{Nd}(\mathrm{III})$ leads to a consecutive precipitation of the two elements.

\section{A R T I C L E I N F O}

\section{Article history:}

Received 8 January 2016

Received in revised form 4 March 2016

Accepted 7 March 2016

Available online 9 March 2016

\section{G R A P H I C A L A B S T R A C T}
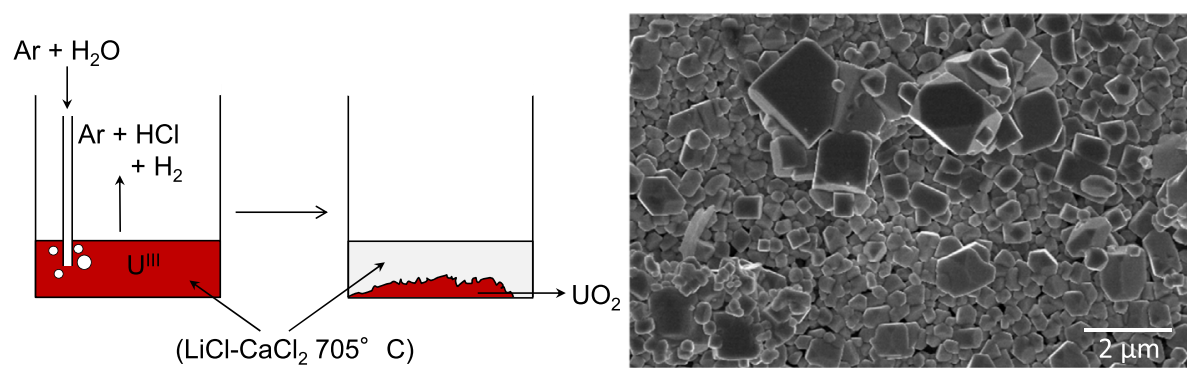

\begin{abstract}
A B S T R A C T
In the context of pyrochemical processes for nuclear fuel treatment, the precipitation of uranium (III) in molten salt $\mathrm{LiCl}-\mathrm{CaCl}_{2}(30-70 \mathrm{~mol} \%)$ at $705^{\circ} \mathrm{C}$ is studied. First, this molten chloride is characterized with the determination of the water dissociation constant. With a value of $10^{-4.0}$, the salt has oxoacid properties. Then, the uranium (III) precipitation using wet argon sparging is studied. The salt is prepared using $\mathrm{UCl}_{3}$ precursor. At the end of the precipitation, the salt is totally free of solubilized uranium. The main part is converted into $\mathrm{UO}_{2}$ powder but some uranium is lost during the process due to the volatility of uranium chloride. The main impurity of the resulting powder is calcium. The consequences of oxidative and reductive conditions on precipitation are studied. Finally, coprecipitation of uranium (III) and neodymium (III) is studied, showing a higher sensitivity of uranium (III) than neodymium (III) to precipitation.
\end{abstract}

() 2016 Elsevier B.V. All rights reserved.

\section{Introduction}

Spent nuclear fuel management represents one of the most important issues related to the sustainable development of nuclear energy. In France, spent nuclear fuel is currently recycled at

\footnotetext{
* Corresponding author. Current address: European Commission, Joint Research Centre (JRC), Institute for Transuranium Elements (ITU), Postfach 2340, 76125 Karlsruhe, Germany.

E-mail address: jean-francois.vigier@ec.europa.eu (J.-F. Vigier).
}

industrial scale by the hydrometallurgical PUREX process allowing selective recovery of uranium and plutonium for new fuel fabrication. However, with the development of Generation IV reactors, many researches are still focused on new processes, for minor actinides (americium, neptunium and curium) recovery together with uranium and plutonium. For such applications, alternatives to hydrometallurgical processes are also considered, such as pyrochemical processes showing specific advantages: no sensitivity to radiolysis and a reduced criticality risk for example [1,2].

At CEA (French Atomic Energy and Alternative Energies Commission), one of the considered pyrochemical processes is based on 
selective liquid-liquid reductive extraction of actinides versus lanthanides in a molten aluminium alloy [3] (Fig. 1). After this separating step, actinides are back-extracted in the $\mathrm{LiCl}-\mathrm{CaCl}_{2}$ (30-70 mol\%) molten chloride salt at high temperature $\left(705^{\circ} \mathrm{C}\right)[4]$. Solubilized at the oxidation state (III) in the salt, actinides conversion to $\mathrm{AnO}_{2}$ oxides needs to be considered for the fabrication of new nuclear fuel. The present study is mainly focused on $\mathrm{U}(\mathrm{III})$ chloride conversion to $\mathrm{UO}_{2}$ in the molten $\mathrm{LiCl}-\mathrm{CaCl}_{2}$.

The chemistry of uranium in molten chloride is well described by Martinot et al. [5] through the Pourbaix diagram in eutectic LiCl$\mathrm{KCl}$ at $450{ }^{\circ} \mathrm{C}$. This diagram presents the stability of soluble and insoluble uranium species as a function of the potential and the $\mathrm{O}^{2-}$ concentration in the salt. It highlights the rich diversity of stable oxidation states of uranium in these medias with, for low $\mathrm{O}^{2-}$ concentration the presence of many soluble species $\mathrm{U}^{3+}, \mathrm{U}^{4+}, \mathrm{UO}_{2}^{+}$, $\mathrm{UO}_{2}^{2+}$ and for higher $\mathrm{O}^{2-}$ concentration, the insoluble species $\mathrm{UO}_{2}$, $\mathrm{UO}_{3}$ and $\mathrm{U}_{3} \mathrm{O}_{8}$. Metallic uranium is also stable in molten chloride at the lowest potential. Thereby, in order to obtain solid $\mathrm{UO}_{2}$ from solubilized $\mathrm{U}^{3+}$, the precipitation method needs to provide oxide ion $\mathrm{O}^{2-}$ and to be moderately oxidizing for an oxidation of uranium from III to IV, but not higher. Moreover, different uranium precipitates are formed by varying the molten chloride nature. If no solid uranium (III) compounds was reported in these medias and uranium (IV) is only presented as $\mathrm{UO}_{2}$ [5-9], higher oxidation states can produce numerous compounds as $\mathrm{MUO}_{3}, \mathrm{M}_{2} \mathrm{UO}_{4}$, $\mathrm{M}_{2} \mathrm{U}_{2} \mathrm{O}_{7}\left(\mathrm{M}=\right.$ alkali metal) or $\mathrm{M}^{\prime} \mathrm{UO}_{4}, \mathrm{M}^{\prime} \mathrm{U}_{2} \mathrm{O}_{7}\left(\mathrm{M}^{\prime}\right.$ = alkaline earth metal) $[5,10]$. These compounds emphasize the importance of a moderate oxidative way of precipitation to avoid an oxidation over the oxidation state (IV) and a pollution of the final powder with alkaline or alkaline hearth metal.

In this study, the precipitation of uranium (III) was done by wet argon sparging. This technique has been patented for pyroprocessing of actinides from spent nuclear fuel [11], and a similar technique has been used in the past for crystal growth of $\mathrm{UO}_{2}$ and $\mathrm{ThO}_{2}$ in fluoride molten salt [12]. Wet argon sparging has already shown interesting performances for the precipitation of cerium (III) and neodymium (III) $[13,14]$. In the first part of the publication, the Oxo-acidity property of the salt $\mathrm{LiCl}-\mathrm{CaCl}_{2}(30-70 \mathrm{~mol} \%$ ) has been determined using potentiometric method. The precipitation of uranium has been then studied in several conditions (standard, oxidative and reductive). Finally, as a preliminary study of uranium (III) co-precipitation with others actinides (III) (plutonium and/or minor actinides), the co-precipitation of uranium (III) and neodymium (III) by wet argon sparging has been investigated.

\section{Experimental}

\subsection{General features}

LiCl- $\mathrm{CaCl}_{2}$ (30-70 mol\%) melt was prepared from LiCl (Sigma Aldrich, 99\%) and $\mathrm{CaCl}_{2}$ (Alpha Aesar 96\%). Uranium chloride was synthesized at the laboratory and anhydrous $\mathrm{NdCl}_{3}$ (Aldrich, 99.9\% under argon) was used. The $\mathrm{LiCl}-\mathrm{CaCl}_{2}$ salt mixture was introduced in a vitreous carbon crucible (SGL Carbon, Sigradur type), itself placed into a leak tight quartz reactor heated in a vertical tubular furnace. The salt was first dehydrated by heating under vacuum at $300{ }^{\circ} \mathrm{C}$ during $6 \mathrm{~h}$, and then heated to $705{ }^{\circ} \mathrm{C}\left(2{ }^{\circ} \mathrm{C} \min ^{-1}\right)$ under $2 \mathrm{NL} \mathrm{h}^{-1}$ of dry argon (Air Liquide, $\mathrm{Ar} \mathrm{N} 60, \mathrm{H}_{2} \mathrm{O}<0.6 \mathrm{ppm}$, $\mathrm{O}_{2}<0.1 \mathrm{ppm}$ ). The complete fusion of the salt occurred at $680{ }^{\circ} \mathrm{C}$ [15]. The bath temperature was measured with an S-type thermocouple $\left( \pm 1{ }^{\circ} \mathrm{C}\right)$ sheathed into a glassy carbon closed end tube (Carbone Lorraine, V25 type) immersed into the molten salt. Uranium trichloride and/or neodymium trichloride was then added to the previously dehydrated molten $\mathrm{LiCl}-\mathrm{CaCl}_{2}$.

The experimental device used for precipitation experiments is Fig. 2 and has been previously described [13]. Uranium precipitation was performed by sparging wet argon through a glassy carbon tube (SGL Carbon, Sigradur type) in the molten chloride. Wet argon was obtained by argon sparging ( $2 \mathrm{NL} \mathrm{h}^{-1}$ through a PTFE frit) in water at $20^{\circ} \mathrm{C}$, in a dedicated bottle placed upstream of the reactor. The saturation pressure of water vapor in these temperature conditions is $2352 \mathrm{~Pa}$ [16]. The reaction of water in the fused salt produced hydrochloric acid gas neutralized downstream by a $\sim 0.1 \mathrm{M} \mathrm{NaOH}$ solution.

After the precipitation, wet argon was replaced by dry argon. After salt sampling for further ICP analyses, the salt was cooled to room temperature under argon atmosphere, recovered from the crucible and dissolved in $100 \mathrm{~mL}$ of water. The precipitate was filtered, washed several times with deionized water and dried at room temperature. The final powder was analyzed by XRD, TGA and SEM analysis.

\section{2. $\mathrm{UCl}_{3}$ synthesis}

Uranium trichloride $\left(\mathrm{UCl}_{3}\right)$ was selected as starting material for $\mathrm{U}(\mathrm{III})$ conversion experiments in molten salt and was synthesized from uranium oxide $\mathrm{U}_{3} \mathrm{O}_{8}$ in two steps: conversion to $\mathrm{UCl}_{4}$ and then to $\mathrm{UCl}_{3}$. Uranium chlorides being highly hygroscopic products, they were stored and manipulated in Argon glove box.

$\mathrm{UCl}_{4}$ was synthesized by action of $\mathrm{CCl}_{4}$ vapour in argon flow $\left(5 \mathrm{NL} \mathrm{h}^{-1}\right.$ ) on $70 \mathrm{~g}$ of $\mathrm{U}_{3} \mathrm{O}_{8}$ at $500{ }^{\circ} \mathrm{C}$ [17]. The experimental device and crucibles previously described were used, replacing the water by $\mathrm{CCl}_{4}$ in the bottle placed upstream of the reactor. This way of chlorination was convenient to produce large amount of material, however some uranium was lost due to the formation of volatile species $(\mathrm{U}(\mathrm{VI})$ and $\mathrm{U}(\mathrm{V})$ chlorides) which condensed on the cold parts of the reactor. The reaction was done twice (first $24 \mathrm{~h}$ and then $4 \mathrm{~h}$ ) to improve the conversion yield. $52.6 \mathrm{~g}$ of well crystalline green powder, characteristic of $\mathrm{UCl}_{4}$ were obtained.

The second step consisted in reducing a slight excess of $\mathrm{UCl}_{4}$ $(52.6 \mathrm{~g})$ in contact with metallic zinc (4.29 g) at $500{ }^{\circ} \mathrm{C}[18]$ and under argon flow $\left(2 \mathrm{NL} \mathrm{h}^{-1}\right)$ in the quartz reactor, following the equation:

$$
2 \mathrm{UCl}_{4}+\mathrm{Zn}^{0}=2 \mathrm{UCl}_{3}+\mathrm{ZnCl}_{2}
$$

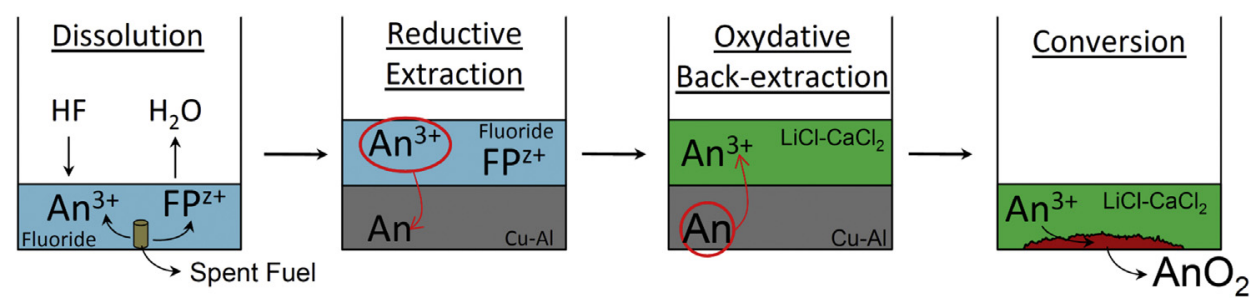

Fig. 1. Schematic description of the main steps considered in the CEA pyrochemical liquid-liquid extraction process. "FP" stands for Fission Product, and "An" for Actinides. 


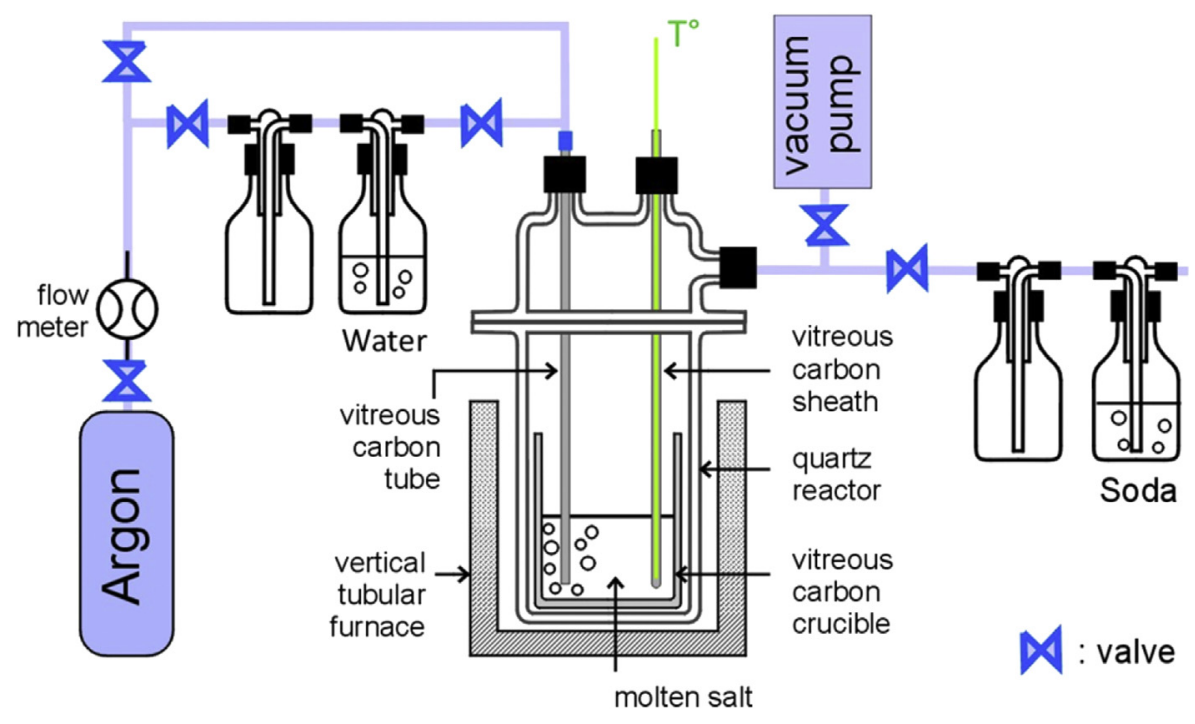

Fig. 2. Experimental set-up for uranium precipitation in molten $\mathrm{LiCl}-\mathrm{CaCl}_{2}$ by humid argon sparging.

The reaction was maintained for $3 \mathrm{~h}$, and then the temperature was slowly increased up to $800{ }^{\circ} \mathrm{C}\left(0.5{ }^{\circ} \mathrm{C} \mathrm{min}{ }^{-1}\right)$ to release $\mathrm{ZnCl}_{2}$ and the excess of $\mathrm{UCl}_{4}$ by volatilization (Table 1). $39 \mathrm{~g}$ of acicular dark powder were obtained after cooling at room temperature. The absence of zinc was checked by ICP-AES analysis, and $\mathrm{UCl}_{3}$ was clearly identified by X-Ray diffraction (Fig. 3). The $\mathrm{UCl}_{3}$ synthesized powder contained less than $7 \mathrm{wt}$.\% of $\mathrm{UO}_{2}$, evaluated by selective dissolution of the powder in water, filtration and weighting of the insoluble $\mathrm{UO}_{2}$. This gave a reaction yield of about $80 \%$. In the following text the term " $\mathrm{UCl}_{3}$ " will refer to this powder.

\subsection{Uranium precipitation experiments}

Different uranium precipitation experiments were conducted. The precipitation conditions slightly differed from one to other (atmosphere, redox conditions, Nd coprecipitation) and are summarized in Table 2. $0.9-1.45 \mathrm{~g}$ of $\mathrm{UCl}_{3}$ were added to $20 \mathrm{~g}$ of previously dehydrated and molten $\mathrm{LiCl}-\mathrm{CaCl}_{2}$ salt. The precipitation experiments were run at $705^{\circ} \mathrm{C}$ for $1 \mathrm{~h}-6 \mathrm{~h}$ with wet argon flow at $2 \mathrm{NL} \mathrm{h}^{-1}$ (saturated at $20^{\circ} \mathrm{C}$ ). The first experiment $\mathrm{U} 1$ was conducted as previously described with $1.45 \mathrm{~g}$ of $\mathrm{UCl}_{3}$ during $6 \mathrm{~h}$. In the second one (U2), the wet argon flow in the molten salt was slightly contaminated with oxygen. The amount of air introduced in the wet argon atmosphere was not well controlled but was estimated to be around $1 \%$. In the third one (U3), a $0.61 \mathrm{~g}$ piece of metallic uranium was added to the $\mathrm{LiCl}-\mathrm{CaCl}_{2}-\mathrm{UCl}_{3}$ solution before wet argon sparging. The objective was to maintain reductive conditions in the molten salt during uranium precipitation. The amount of metallic uranium consumed during the precipitation was determined from the mass difference of the metal before and after the precipitation.

Two uranium-neodymium co-precipitation (U-Nd1 and U-Nd2), with an equimolar proportion of the two elements $\left(\mathrm{n}_{\mathrm{U}}=\mathrm{n}_{\mathrm{Nd}}=2.6 \mathrm{mmol}\right)$ were run during $1 \mathrm{~h}$ and $6 \mathrm{~h}$, respectively.

Table 1

Melting and boiling temperatures of the compounds related to the $\mathrm{UCl}_{3}$ synthesis.

\begin{tabular}{llcl}
\hline Compound & Melting point $\left({ }^{\circ} \mathrm{C}\right)$ & Boiling point $\left({ }^{\circ} \mathrm{C}\right)$ & Reference \\
\hline $\mathrm{Zn}^{0}$ & 405 & 907 & {$[16]$} \\
$\mathrm{UCl}_{4}$ & 590 & 789 & {$[17]$} \\
$\mathrm{ZnCl}_{2}$ & 283 & 732 & {$[16]$} \\
$\mathrm{UCl}_{3}$ & 835 & 1657 & {$[17]$} \\
\hline
\end{tabular}

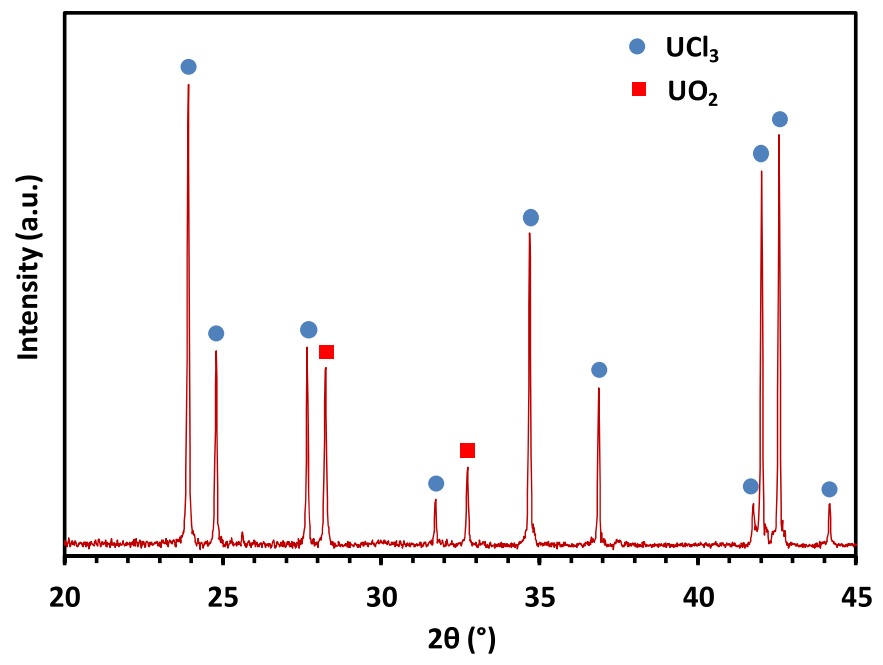

Fig. 3. XRD patterns of the " $\mathrm{UCl}_{3}$ " powder used as starting material for the preparation of molten salt containing solubilized uranium (III).

\subsection{Electrodes and potentiometric instrumentation}

In order to characterize the "oxoacid power" of the $\mathrm{LiCl}-\mathrm{CaCl}_{2}$ molten salt, $\mathrm{O}^{2-}$ oxide ions concentration in the molten salt was measured by potentiometry.

Potentiometric measurements were performed with a twoelectrode set-up connected to a potentiostat-galvanostat Autolab PG Stat 30 controlled with the Autolab software package (Metrohm).

The electrodes used consisted of an $\mathrm{AgCl} / \mathrm{Ag}$ reference electrode and a selective oxide ions membrane electrode (YSZE electrode). The reference electrode was made of a silver wire $(1 \mathrm{~mm} \emptyset$, Goodfellow, 99.99\%) dipped into a closed-end mullite tube (OMG France, $6-4 \mathrm{~mm} \varnothing$ ) containing a $0.75 \mathrm{~mol} \mathrm{~kg}^{-1}$ silver chloride (Aldrich, 99\%) solution in the $\mathrm{LiCl}-\mathrm{CaCl}_{2}$. The oxide ions membrane electrode was constituted by a closed-end tube of $\mathrm{ZrO}_{2}$ stabilized with 8 wt.\% $\mathrm{Y}_{2} \mathrm{O}_{3}$ (Sceram, 6-4 mm Ø), containing a constant $\mathrm{O}^{2-}$ ion concentration $\left(0.1 \mathrm{~mol} \mathrm{~kg}^{-1}\right.$ in $\mathrm{LiCl}-\mathrm{CaCl}_{2}$, introduced as solid $\mathrm{Li}_{2} \mathrm{CO}_{3}$ (Aldrich, 99\%)) and an internal $\mathrm{AgCl} / \mathrm{Ag}$ reference $\left(0.75 \mathrm{~mol} \mathrm{~kg}^{-1} \mathrm{AgCl}\right.$ with a $1 \mathrm{~mm} \varnothing$ silver wire (Goodfellow, 
Table 2

Uranium precipitation conditions.

\begin{tabular}{|c|c|c|c|c|c|}
\hline Experiment & U1 & $\mathrm{U} 2$ & U3 & U-Nd1 & U-Nd2 \\
\hline Temperature $\left({ }^{\circ} \mathrm{C}\right)$ & 705 & 705 & 705 & 705 & 705 \\
\hline $\begin{array}{l}\text { Wet argon flow }\left(\mathrm{NL} \mathrm{h}^{-1}\right) \\
\left.\text { (saturated at } 20^{\circ} \mathrm{C}\right)\end{array}$ & 2 & 2 & 2 & 2 & 2 \\
\hline Atmosphere & $\mathrm{Ar} / \mathrm{H}_{2} \mathrm{O}$ & $\mathrm{Ar} / \mathrm{H}_{2} \mathrm{O}$ with few $\mathrm{O}_{2}(\sim 1 \%)$ & $\mathrm{Ar} / \mathrm{H}_{2} \mathrm{O}$ & $\mathrm{Ar} / \mathrm{H}_{2} \mathrm{O}$ & $\mathrm{Ar} / \mathrm{H}_{2} \mathrm{O}$ \\
\hline Duration (h) & 6 & 6 & 6 & 6 & 1 \\
\hline $\mathrm{n}_{\mathrm{H} 2 \mathrm{O}}$ introduced (mmol) & 11.3 & 11.3 & 11.3 & 11.3 & 1.9 \\
\hline $\mathrm{LiCl}-\mathrm{CaCl}_{2}(\mathrm{~g})$ & 20 & 20 & 20 & 20 & 20 \\
\hline $\mathrm{UCl}_{3}(\mathrm{~g})$ & 1.45 & 1.45 & 1.45 & 0.9 & 0.9 \\
\hline Metallic U (g) & 0 & 0 & 0.61 & 0 & 0 \\
\hline $\mathrm{NdCl}_{3}(\mathrm{~g})$ & 0 & 0 & 0 & 0.65 & 0.65 \\
\hline
\end{tabular}

\section{$99.99 \%)$ ).}

$\mathrm{O}^{2-}$ concentration was determined by measuring the e. m.f. between the reference and the YSZE electrode and using a calibration curve obtained by adding controlled quantities of $\mathrm{Li}_{2} \mathrm{CO}_{3}$ (Aldrich, 99\%) in the salt under Ar atmosphere [19].

\subsection{Determination of the oxoacidity constant of the $\mathrm{HCl} / \mathrm{H}_{2} \mathrm{O}$ system}

For this experiment, specific anhydrous reactants were used. $30 \mathrm{~g}$ of $\mathrm{LiCl}-\mathrm{CaCl}_{2}$ (30-70 mol\%) were prepared from $\mathrm{LiCl}$ (Sigma Aldrich, 99.998\%, sealed under $\mathrm{Ar}$ ) and $\mathrm{CaCl}_{2}$ (Sigma Aldrich, $99.99 \%$, sealed under Ar) and were heated to $705{ }^{\circ} \mathrm{C}\left(2{ }^{\circ} \mathrm{C} \mathrm{min}^{-1}\right)$ under argon atmosphere. Reference and YSZE electrodes were introduced in the molten salt. Argon with different $\mathrm{P}_{\mathrm{HCl}}^{2} / \mathrm{P}_{\mathrm{H} 2 \mathrm{O}}$ ratios was bubbled in the molten salt and the YZSE electrode stabilized potential was measured versus the reference electrode for each ratio, as described by Castrillejo et al. [20].

The experimental device and crucibles previously described were used, replacing the water by $\mathrm{HCl}$ solution in the bottle placed upstream of the reactor. The different $\mathrm{HCl}$ and $\mathrm{H}_{2} \mathrm{O}$ partial pressure ratios were obtained by bubbling argon $\left(2 \mathrm{NL} \mathrm{h}^{-1}\right)$ through thermostated $\mathrm{HCl}$ solution at $25{ }^{\circ} \mathrm{C}$ with different successive concentrations (35.6\%, 33.6\%, 31.6\%, 29.7\% and 27.7\%). The partial pressures of $\mathrm{HCl}$ and $\mathrm{H}_{2} \mathrm{O}$ in the argon flow were deduced using thermodynamic table [21]. In order to get a better stabilization of the pressure ratio, two $\mathrm{HCl}$ bottles were serially connected. The two bottles were initially filled with $200 \mathrm{~g}$ of $37 \% \mathrm{HCl}$ solution (Rectapur). For each pressure ratio, specific quantities of water were introduced thanks to a dedicated opening, to obtain the respective $\mathrm{HCl}$ solution concentration. After the YSZE electrode potential stabilization, a sample was taken from the second $\mathrm{HCl}$ solution and $\mathrm{HCl}$ concentration was determined with a standard $1 \mathrm{M} \mathrm{NaOH}$ solution titration. Then, controlled quantity of water was introduced in the two $\mathrm{HCl}$ solutions to obtain the next conditions.

\subsection{Analytical techniques}

\subsubsection{Induced coupled plasma analysis-atomic emission} spectroscopy (ICP-AES)

The precipitation yields were calculated from the concentration of soluble uranium and neodymium remaining in the molten salt at the end of the precipitation. The concentrations of soluble species in the salt were measured by Induced Coupled Plasma Atomic Emission Spectroscopy (ICP-AES). About $100 \mathrm{mg}$ of samples, extracted from the hot mixture by suction through a quartz tube at the end of the precipitation, were dissolved in $100 \mathrm{~mL}$ of water and filtered to remove any precipitate. The acidification of the solution with nitric acid stabilized the solubilized elements. The analyses of the solutions gave the amount of unreacted uranium in the molten salt. To avoid any matrix effect on the ICP-AES measurements, the standard range was made with the same concentration of $\mathrm{LiCl}$, $\mathrm{CaCl}_{2}$ and $\mathrm{HNO}_{3}$.

\subsubsection{X-ray diffraction (XRD)}

The precipitates powder X-ray diffraction patterns were recorded using a D8 Advance Bruker diffractometer with $\mathrm{Cu} \mathrm{K} \alpha$ radiation and an energy dispersive detector (sol-X), over a $2 \theta$ range of $10-80^{\circ}$ at $0.02^{\circ}$ increments. The profile fitting and the cell parameters refinements were performed using the powder option of JANA2006 [22].

\subsubsection{Scanning electron microscope (SEM)}

The morphology of the precipitate was observed with a Scanning Electron Microscope (SEM) Hitachi S4700 with Field Emission Gun (FEG), a cathodoluminescence and an Electron Beam Induced Current (EBIC) system.

\subsubsection{Thermogravimetric analysis (TGA)}

Thermal analyses were performed under air atmosphere on a Setsys Evolution Thermogravimetric Analyzer from Setaram, in a temperature range from 100 to $800{ }^{\circ} \mathrm{C}\left(5^{\circ} \mathrm{C} \mathrm{min}{ }^{-1}\right.$ heating speed $)$.

\subsubsection{Conductimetric analysis}

The hydrochloric acid released from the water reaction in molten chloride can be followed by conductimetric evolution of the $\mathrm{NaOH}$ solution placed downstream of the reactor. The technique has been previously described [13]. The $\mathrm{NaOH}$ solution conductivity was continuously measured during the precipitation reaction. Using this method, the hydrochloric acid flow rate $\mathrm{D}_{\mathrm{HCl}}$ released from the molten salt can be compared to the water flow rate $D_{\mathrm{H} 2 \mathrm{O}}$ introduced in the media. For example, the relation $\mathrm{D}_{\mathrm{HCl}}=2 \mathrm{D}_{\mathrm{H} 2 \mathrm{O}}$ was obtained for the reaction described by Equation (2).

\section{Results and discussion}

\subsection{Determination of the oxoacidity constant of the $\mathrm{HCl} / \mathrm{H}_{2} \mathrm{O}$ system}

Processes, like oxides solubilization or precipitation can be estimated a priori by determining the oxoacidity properties of the molten salt mixtures. The more the oxoacidity properties are important, the more oxides can be solubilized in the salt. For precipitation, molten salt with oxobasic properties are often selected, such as $\mathrm{NaCl}-\mathrm{KCl}$ and $\mathrm{NaCl}-\mathrm{CsCl}$ [23]. The oxoacidity properties are generally characterized by the equilibrium constant $\mathrm{K}_{\mathrm{H} 2 \mathrm{O}}$ of the reaction 2 in the considered molten salt $[19,24]$ :

$$
\begin{aligned}
& \mathrm{H}_{2} \mathrm{O}_{(\mathrm{g})}+2 \mathrm{Cl}_{(\text {salt })}^{-}=\mathrm{O}^{2-}{ }_{(\text {salt })}+2 \mathrm{HCl}_{(\mathrm{g})} \\
& K_{\mathrm{H}_{2} \mathrm{O}}=\frac{P_{\mathrm{HCl}}^{2} \cdot\left[\mathrm{O}^{2-}\right]}{P_{\mathrm{H}_{2} \mathrm{O}} \cdot\left[\mathrm{Cl}^{-}\right]}
\end{aligned}
$$


With $\mathrm{K}_{\mathrm{H} 2 \mathrm{O}}$ (atm.mol.kg ${ }^{-1}$ ), $\mathrm{P}$ the pressure (atm), $\left[\mathrm{O}^{2-}\right]$ the oxide concentration $\left(\mathrm{mol} . \mathrm{kg}^{-1}\right)$ and the chloride ions activity being taken as unity. The $\mathrm{pO}^{2-}$ value $\left(\mathrm{pO}^{2-}=-\log \left(\mathrm{a}^{2}\left(\mathrm{O}^{2-}\right)\right)\right)$ is determined with the potential between the reference and the selective oxide ions membrane electrode (YSZE), following the Nernst's expression:

$E=E^{0}+\frac{2.3 R T}{2 F} p O^{2-}$

According to Equation (3), and using the logarithmic form, $\mathrm{pO}^{2-}$ is given by:

$p O^{2-}=p K_{\mathrm{H}_{2} \mathrm{O}}+\log \left(\frac{P_{\mathrm{HCl}}^{2}}{P_{\mathrm{H}_{2} \mathrm{O}}}\right)$

The experimental $\mathrm{pO}^{2-}$ measurement for different $\mathrm{HCl}$ and $\mathrm{H}_{2} \mathrm{O}$ imposed partial pressures in the molten salt leads to the determination of the oxoacidity constant $\mathrm{K}_{\mathrm{H} 2 \mathrm{O}}$.

To our knowledge, the oxoacidity constant in the $\mathrm{LiCl}-\mathrm{CaCl}_{2}$ molten salt has not been determined yet and this characteristic data is useful for precipitation study. Fig. 4a shows the calibration curve of the YSZE at low $\mathrm{pO}^{2-}$ and its verified Nernstian behavior. The experimental measurement of $\mathrm{pO}^{2-}$ as a function of the partial pressure ratios $\log \left(\mathrm{P}_{\mathrm{HCl}}^{2} / \mathrm{P}_{\mathrm{H} 2 \mathrm{O}}\right)$ leads to a linear variation (Fig. $\left.4 \mathrm{~b}\right)$. A pK $\mathrm{H}_{20}$ value of $4.0( \pm 0.5)$ for $\mathrm{LiCl}-\mathrm{CaCl}_{2}(30-70 \mathrm{~mol} \%)$ at $705{ }^{\circ} \mathrm{C}$ is determined from this variation. Compared to other molten salts and particularly the well-used $\mathrm{LiCl}-\mathrm{KCl}$ salt (Table 3), the $\mathrm{LiCl}-\mathrm{CaCl}_{2}$ salt used in this study shows higher oxoacidity properties, probably due to the presence of the hard divalent cation $\mathrm{Ca}^{2+}$ in its composition. Such a salt is a priori not favorable to precipitation due to its capability to dissolve oxide ions. The choice of this $\mathrm{LiCl}-\mathrm{CaCl}_{2}$ "oxoacidic" salt was motivated by the optimization of the upstream step in the pyrochemical process (ie. actinides back extraction from a metallic aluminium alloy) [25]. However, the more important the oxoacidity properties are, the more the water reaction in the salt is displaced to the right (Equation (2)). This is in favor to the wet argon sparging precipitation and could compensate the first effect.

\subsection{Uranium precipitation by wet argon sparging}

The uranium (III) precipitation experiment $\mathrm{U} 1$ in molten LiCl$\mathrm{CaCl}_{2}$ (30-70 mol\%) by wet argon sparging leads to a brown-red powder (Fig. 5). Unreacted uranium in the salt is not detected with ICP-AES analyses of the sample taken after the end of precipitation. On this basis, the $\mathrm{U}(\mathrm{III})$ conversion rate is over $99.9 \%$, deduced from the limit detection of the ICP-AES apparatus. Despite the high oxoacidity of the molten salt used in this study, U(III) conversion in molten salt with wet argon sparging is quantitative. However, during the experiment, a part of uranium is volatilized from the molten salt and condenses on the cold parts of the quartz reactor. This can be explained by the formation of $\mathrm{UCl}_{4}$ during the precipitation. Uranium tetrachloride is volatile at the working temperature $\left(\mathrm{T}_{\mathrm{vap}}=789^{\circ} \mathrm{C}[17]\right)$. Due to the use of acidic salt, this volatility is not prevented by complexation $[27,28]$. The amount of uranium lost by volatilisation is deduced from the weight of the final precipitate. It is estimated at $26 \%$ of the initial uranium introduced in the molten salt. This lost is not conflicting with the quantitative conversion rate determined by ICP analysis, but has to be considered as a secondary phenomenon. This volatility is a potential issue for the process.

The precipitate is clearly identified as crystalline $\mathrm{UO}_{2}$ single phase by XRD analysis. The cell parameter of 5.471(1) $\AA$ is in good agreement with the published value [29]. This lattice parameter indicates that the uranium oxide has a stoichiometric composition $\mathrm{UO}_{2.00}$. The TGA analysis shows a weigh increase of $3.75 \%$ during
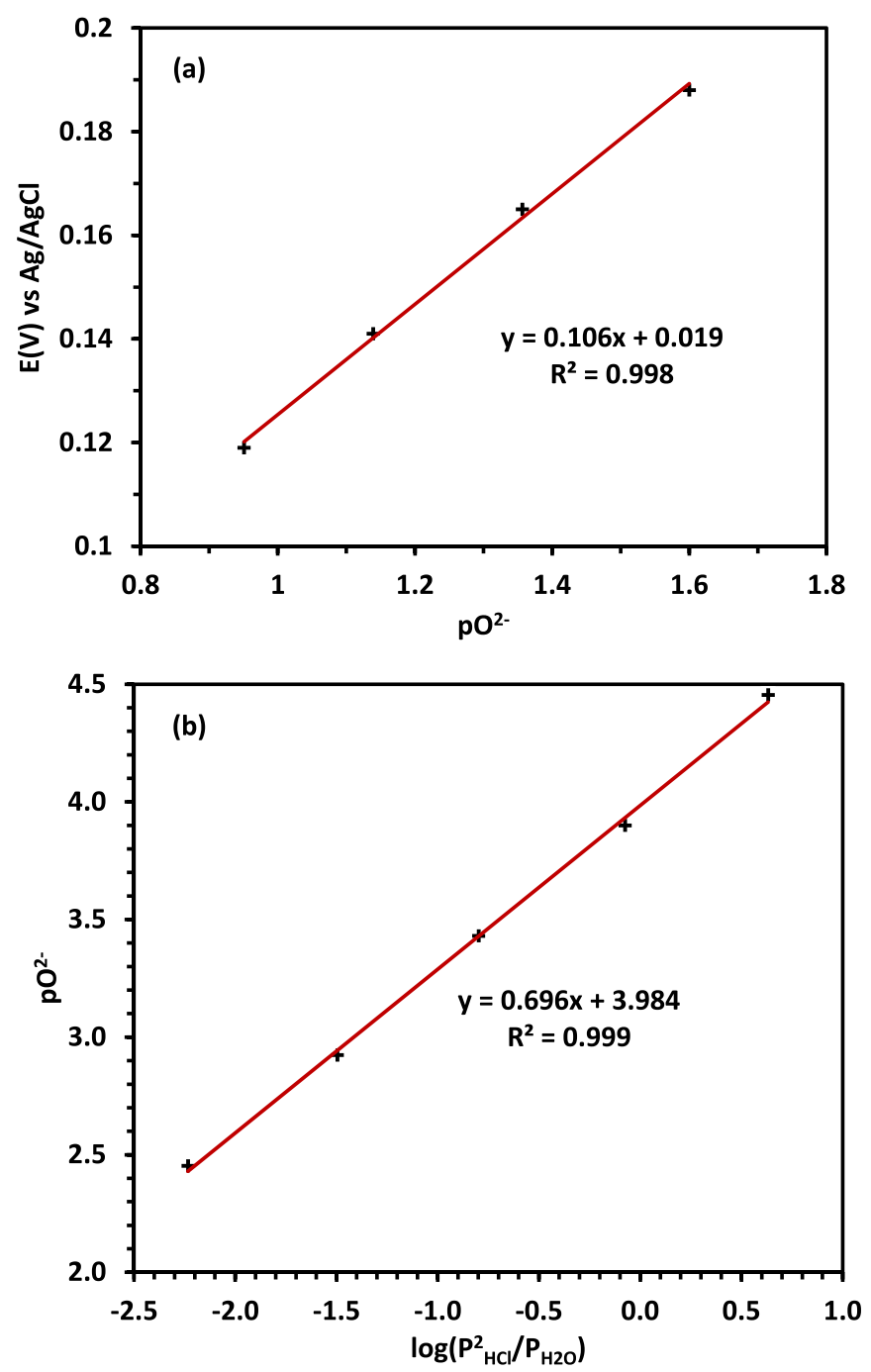

Fig. 4. (a) Calibration of the specific oxide ions electrode (YSZE) in $\mathrm{LiCl}-\mathrm{CaCl}_{2}$ (30-70 mol\%) at $705{ }^{\circ} \mathrm{C}$. (b) Variation of the $\mathrm{pO}^{2-}$ of the molten $\mathrm{LiCl}-\mathrm{CaCl}_{2}(30-70 \mathrm{~mol}$ $\%$ ) at $705{ }^{\circ} \mathrm{C}$ under different $\mathrm{HCl}$ and $\mathrm{H}_{2} \mathrm{O}$ partial pressures.

the oxidation of the precipitate under air atmosphere (Fig. 6) which confirms the uranium dioxide formation (theoretical increase from $\mathrm{UO}_{2}$ to $\mathrm{U}_{3} \mathrm{O}_{8}, 3.95 \%$ ). The morphology of $\mathrm{UO}_{2}$ shows truncated cubic crystals, with grain size from 0.2 to $2 \mu \mathrm{m}$ (Fig. 7). The precipitation reaction can thus be written:

$\mathrm{UCl}_{3(\text { salt })}+2 \mathrm{H}_{2} \mathrm{O}_{(\mathrm{g})}=\mathrm{UO}_{2(\text { solid })}+3 \mathrm{HCl}_{(\mathrm{g})}+1 / 2 \mathrm{H}_{2(\mathrm{~g})}$

The hydrochloric acid production is monitored by the conductivity measurement of the soda solution downstream the reactor. The theoretical evolution of the $\mathrm{NaOH}$ solution conductivity is calculated for two stoichiometries (Table 4). The first one uses the relation $\mathrm{D}_{\mathrm{HCl}}=2 \mathrm{D}_{\mathrm{H} 2 \mathrm{O}}$ (Equation (2)) as previously observed for the total reaction of water during lanthanide precipitation [13]. The second one is also based on a total reaction of the introduced water, but takes into account the oxidation property of water during uranium precipitation (Equation (6)), decreasing the $\mathrm{HCl}$ release due to the hydrogen formation and leading to the relation $\mathrm{D}_{\mathrm{HCl}}=1.5 \mathrm{D}_{\mathrm{H} 2 \mathrm{O}}$. The experimental and calculated evolutions of the conductivity are presented in the Fig. 8. The experimental curve shift is due to the gas volume of reactor and safety bottle between the molten salt and the soda solution which delays the hydrochloric 
Table 3

Comparison between $\mathrm{K}_{\mathrm{H} 2 \mathrm{O}}$ of the molten $\mathrm{LiCl}-\mathrm{CaCl}_{2}(30-70 \mathrm{~mol} \%)$ at $705{ }^{\circ} \mathrm{C}$ and other molten salts.

\begin{tabular}{|c|c|c|c|c|}
\hline Molten chloride & Molar fraction (\%) & $\mathrm{pK}_{\mathrm{H} 2 \mathrm{O}}\left(\mathrm{K}_{\mathrm{H} 2 \mathrm{O}}\right.$ in atm.mol.kg $\left.{ }^{-1}\right)$ & Temperature $\left({ }^{\circ} \mathrm{C}\right)$ & Reference \\
\hline $\mathrm{NaCl}-\mathrm{KCl}$ & $50-50$ & 14 & 727 & {$[26]$} \\
\hline $\mathrm{LiCl}-\mathrm{KCl}$ & $45-55$ & 6.5 & 727 & [26] \\
\hline $\mathrm{CaCl}_{2}-\mathrm{NaCl}-\mathrm{KCl}$ & $10-45-45$ & 5.2 & 727 & [26] \\
\hline $\mathrm{LiCl}-\mathrm{CaCl}_{2}$ & $30-70$ & 4.0 & 705 & This study \\
\hline $\mathrm{MgCl}_{2}-\mathrm{KCl}$ & $50-50$ & 2.4 & 727 & [26] \\
\hline
\end{tabular}

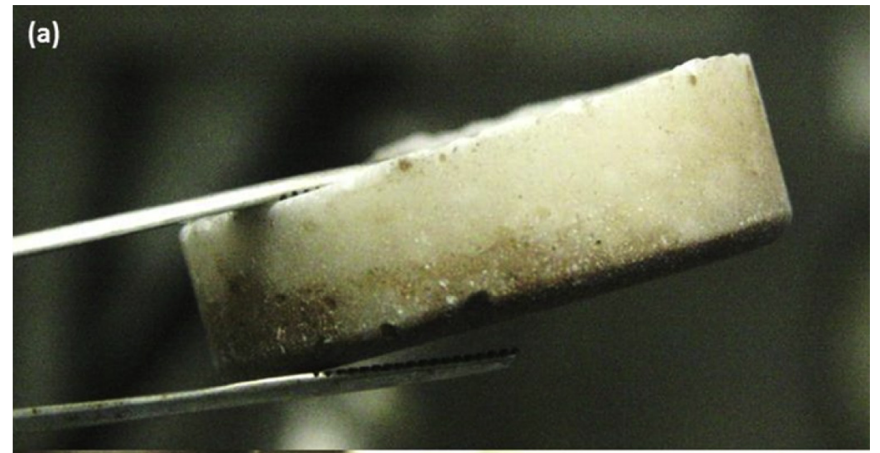

(b)

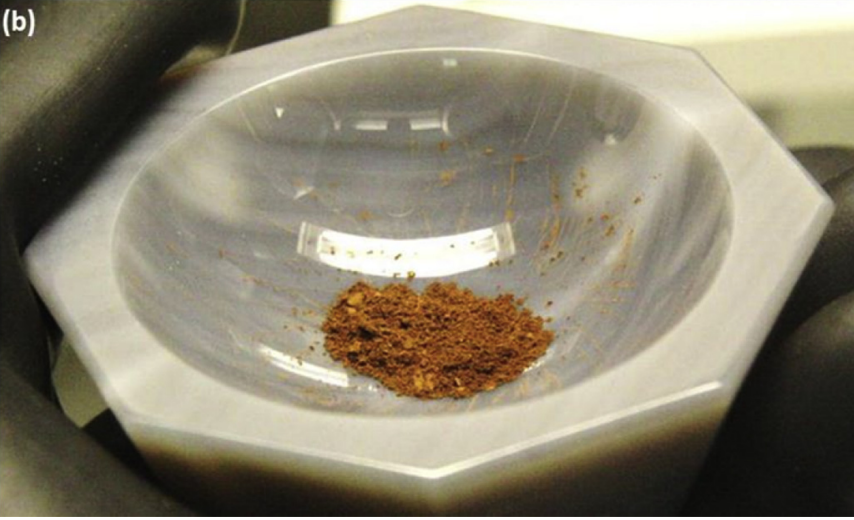

Fig. 5. U1 experiment (a) Picture of $\mathrm{LiCl}-\mathrm{CaCl}_{2}(30-70 \mathrm{~mol} \%)$ salt after the end of precipitation and cooling at room temperature containing the uranium precipitate at the bottom. (b) Picture of uranium precipitate after dissolution of the salt in water, filtration and drying.

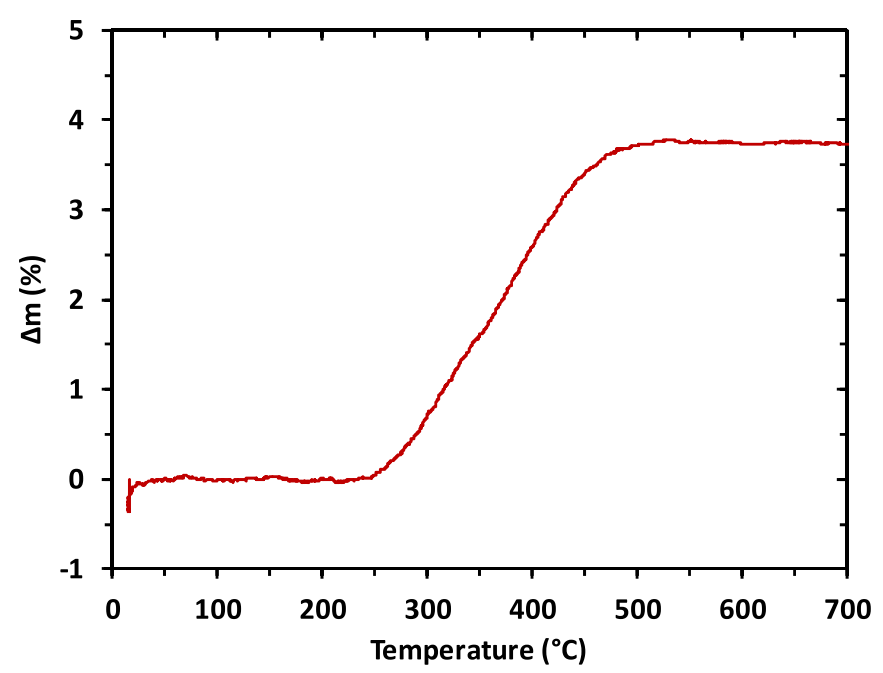

Fig. 6. TGA analysis of uranium precipitate obtained by precipitation of $5 \mathrm{wt} \% \mathrm{U}(\mathrm{III})$ in LiCl-CaCl2 (30-70 mol\%) at $705{ }^{\circ} \mathrm{C}$ using wet argon sparging (U1 experiment).

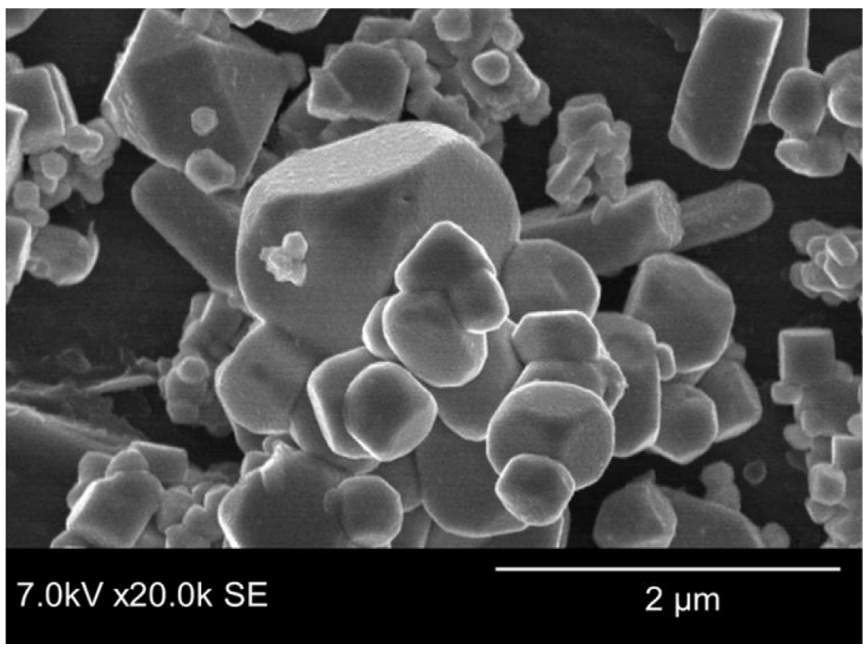

Fig. 7. SEM picture of uranium precipitate showing the morphology of $\mathrm{UO}_{2}$ crystals.

flow in the soda bottle. Considering this equation was already proved by XRD analysis of precipitate, this conductivity variation highlights the total reaction of the introduced water in the molten salt for uranium precipitation. The experimental results are closed to the second model evolution, in agreement with the precipitation reaction 6 . Water plays two roles during the uranium (III) precipitation: it oxidizes the actinide (III) to oxidation state (IV) with a release of hydrogen, and it provides oxide ions for the conversion of soluble uranium chloride to insoluble uranium oxide. In contrast to cerium (III) precipitation by wet argon studied previously and giving a mixture of $\mathrm{Ce}^{\mathrm{III}} \mathrm{OCl}$ and $\mathrm{Ce}^{\mathrm{IV}} \mathrm{O}_{2}$ [13], all the uranium (III) is oxidized into uranium (IV). A part of U(IV) is volatilized as $\mathrm{UCl}_{4}$ and the main part is precipitated, giving uranium dioxide suitable for the fabrication of new nuclear fuel.

The possible calcium and lithium contamination of the precipitate (coming from the solvent) has been checked. A part of the uranium oxide was dissolved in nitric acid and analysed by ICP-AES. The precipitate contains $1.2 \mathrm{wt} \%$ of calcium. The lithium concentration is under the apparatus limit detection which corresponds to less than $0.01 \mathrm{wt} \%$ of the precipitate.

In the second experiment, the accidental introduction of oxygen during the precipitation has allowed to study the precipitation in more oxidative conditions. The presence of oxygen contamination has significant consequence on the final uranium precipitate (Table 5). The precipitate loses its characteristic brown-red colour and is a black powder (Fig. 9). The XRD pattern shows a biphasic composition (Fig. 10). The $\mathrm{UO}_{2}$ peaks, with the same lattice parameter 5.471(1) A as observed for U1 experiment, have shoulders at high angles. These peaks show the presence of a second fluorite compound with a smaller cell parameter, 5.435(2) Å. The calcium contamination, controlled after dissolution with ICP-AES analysis, is around $10 \mathrm{wt} \%$. Due to the strong increase of calcium contamination compared to experiment $\mathrm{U} 1$, the second fluorite 
Table 4

Experimental and calculated data for precipitation and the maximal conductivity evolution of the soda solution downstream the reactor.

\begin{tabular}{|c|c|c|c|}
\hline Experimental data & & Calculated data & \\
\hline Ar flow rate & $2 \mathrm{~L} \mathrm{~h}^{-1}$ & $\mathrm{H}_{2} \mathrm{O}$ partial vapor pressure [16] & $2352 \mathrm{~Pa}$ \\
\hline $\mathrm{H}_{2} \mathrm{O}$ temperature & $20{ }^{\circ} \mathrm{C}$ & $\mathrm{H}_{2} \mathrm{O}$ molar flow rate & $0.00189 \mathrm{~mol} \mathrm{~h}^{-1}$ \\
\hline $\mathrm{NaOH}$ solution volume & $500 \mathrm{~mL}$ & $\begin{array}{l}\text { Maximal } \mathrm{HCl} \text { molar flow rate }{ }^{(\mathrm{a})} \text { for } \mathrm{D}_{\mathrm{HCl}}=2 \mathrm{D}_{\mathrm{H} 2 \mathrm{O}} \\
\text { Maximal } \mathrm{HCl} \text { molar flow rate }{ }^{(\mathrm{b})} \text { for } \mathrm{D}_{\mathrm{HCl}}=1.5 \mathrm{D}_{\mathrm{H} 2 \mathrm{O}}\end{array}$ & $\begin{array}{l}0.00377 \mathrm{~mol} \mathrm{~h}^{-1} \\
0.00283 \mathrm{~mol} \mathrm{~h}^{-1}\end{array}$ \\
\hline $\mathrm{NaOH}$ solution concentration & $0.06 \mathrm{~mol} \mathrm{~L}^{-1}$ & $\begin{array}{l}\text { Highest conductivity evolution } \\
\text { Highest conductivity evolution }^{(\mathrm{a})} \text { for } \mathrm{D}_{\mathrm{HCl}}=2 \mathrm{D}_{\mathrm{H} 2 \mathrm{O}} \\
\mathrm{D}_{\mathrm{HCl}}=1.5 \mathrm{D}_{\mathrm{H} 2 \mathrm{O}}\end{array}$ & $\begin{array}{l}-0.92 \mathrm{mS} \mathrm{cm}^{-1} \mathrm{~h}^{-1} \\
-0.69 \mathrm{mS} \mathrm{cm}^{-1} \mathrm{~h}^{-1}\end{array}$ \\
\hline
\end{tabular}

a Considering the reaction: $\mathrm{H}_{2} \mathrm{O}_{(\mathrm{g})}+2 \mathrm{Cl}^{-}{ }_{(\text {salt })}=\mathrm{O}^{2-}{ }_{(\text {salt })}+2 \mathrm{HCl}_{(\mathrm{g})}$.

b Considering the reaction: $2 \mathrm{H}_{2} \mathrm{O}_{(\mathrm{g})}+3 \mathrm{Cl}^{-}$(salt) $+\mathrm{e}^{-}=2 \mathrm{O}^{2-}$ (salt) $+3 \mathrm{HCl}_{(\mathrm{g})}+1 / 2 \mathrm{H}_{2(\mathrm{~g})}$.

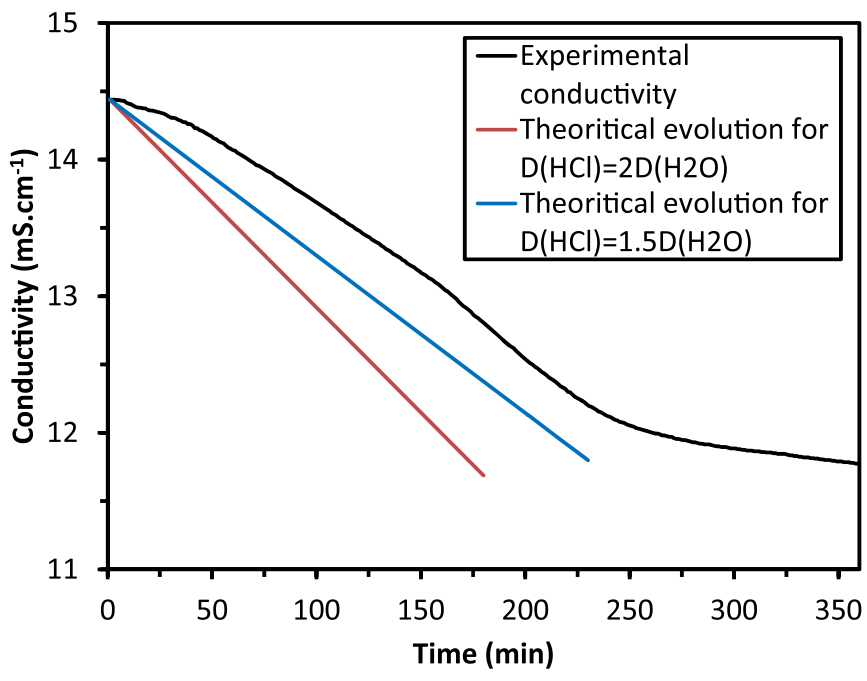

Fig. 8. Experimental and theoretical evolution of the $\mathrm{NaOH}$ solution downstream the reactor, in function of the wet argon sparging time for $5 \mathrm{wt} \% \mathrm{U}(\mathrm{III})$ in $\mathrm{LiCl}-\mathrm{CaCl} 2$ (30-70 mol\%) at $705{ }^{\circ} \mathrm{C}$.
$\left(\mathrm{m}_{\mathrm{UCl}}=1.45 \mathrm{~g}, \mathrm{n}_{\mathrm{U}}=4.2 \mathrm{mmol}\right)$. The ratio gives the global equation:

$\mathrm{U}+2 \mathrm{UCl}_{3}+6 \mathrm{H}_{2} \mathrm{O}_{(\mathrm{g})}=3 \mathrm{UO}_{2}+6 \mathrm{HCl}_{(\mathrm{g})}+3 \mathrm{H}_{2(\mathrm{~g})}$

The calcium contamination of the precipitate is slightly lower, 0.8 wt.\%, than the contamination with the conditions in U1 experiment but is in the same order of magnitude. In these reductive conditions, there is a strong decrease of the uranium lost by volatilisation ( $6 \%$ of initial uranium) which seems to confirm that this phenomenon is caused by volatile $\mathrm{UCl}_{4}$ formation during precipitation, and is mostly avoided with the presence of metallic uranium.

\section{3. $U(I I I)$ and $N d(I I I)$ co-precipitation}

The precipitation of uranium and neodymium in $\mathrm{LiCl}-\mathrm{CaCl}_{2}$ molten salt has been studied through two experiments differentiated by the wet argon sparging time: $6 \mathrm{~h}$ for $\mathrm{U}-\mathrm{Nd} 1 \mathrm{and} 1 \mathrm{~h}$ for $\mathrm{U}-$ Nd2 (Table 2). The XRD patterns of the precipitates are shown in Fig. 11. For $\mathrm{U}-\mathrm{Nd} 1$, the precipitate is a mixture of $\mathrm{NdOCl}$ and $\mathrm{UO}_{2}$. Uranium and neodymium seem to react independently during the

Table 5

Experimental data for $\mathrm{U}(\mathrm{III})$ precipitation experiments at $5 \mathrm{wt} \%$ in $\mathrm{LiCl}-\mathrm{CaCl}_{2}(30-70 \mathrm{~mol} \%)$ at $705{ }^{\circ} \mathrm{C}$ using wet argon sparging.

\begin{tabular}{|c|c|c|c|}
\hline Experiment & U1 & $\mathrm{U} 2$ & U3 \\
\hline Specific conditions & - & $\mathrm{O}_{2}$ impurities in wet argon & Excess of $U^{0}$ in the salt \\
\hline Colour of precipitate & Brown-Red & Black & Brown-Red \\
\hline Calcium content in the precipitate (wt\%) & 1.2 & 10 & 0.8 \\
\hline Uranium lost by volatilization (\%) & 26 & 28 & 6 \\
\hline Lattice parameter of $\mathrm{UO}_{2}(\AA)$ & $5.471(1)$ & $5.471(1)$ & $5.470(1)$ \\
\hline Lattice parameter of the second fluorite phase $(\AA)$ & - & $5.435(2)$ & - \\
\hline
\end{tabular}

phase detected in the powder can be attributed to $\mathrm{Ca}_{\mathrm{y}} \mathrm{U}_{1-\mathrm{y}} \mathrm{O}_{2+\mathrm{x}}$ solid solution [30,31]. This second phase could be also attributed to $\mathrm{UO}_{2+\mathrm{x}}$, with a composition close to the $\mathrm{U}_{4} \mathrm{O}_{9}$ oxide $(\mathrm{a} / 4=5.441(1) \AA$ [27]), due to a partial oxidation of uranium over the oxidation state (IV) induced by the presence of oxygen.

These experiments are a good illustration of the importance of working under moderate oxidative conditions and show the negative consequences of oxygen in wet argon on uranium precipitate in a nuclear fuel fabrication context.

The U3 experiment was undertaken to study the precipitation in more reductive conditions. The uranium (III) precipitation by wet argon sparging is done in presence of metallic uranium in the molten salt. These reductive conditions have no significant consequence on the nature of the uranium precipitate, leading to a brown-red powder, identified by XRD as a single phase $\mathrm{UO}_{2}$ with a cell parameter $\mathrm{a}=5.470$ (1) A cell parameter (Fig. 10). During the precipitation, $0.51 \mathrm{~g}$ of metallic uranium is consumed $(2.1 \mathrm{mmol})$, which is significant compared to the amount of $\mathrm{UCl}_{3}$ used co-precipitation. The $\mathrm{UO}_{2}$ lattice parameter is $5.470(1) \AA$, similar than for $U$ precipitation without neodymium. Therefore, there is not significant introduction of neodymium in this oxide [32]. In the same way, the introduction of uranium is not significant in neodymium oxychloride which crystallizes with lattice parameters $(\mathrm{a}=4.025(1) \AA .6 .775(1) \AA)$ close to the $\mathrm{NdOCl}$ reported in literature ( $\mathrm{a}=4.025(1) \AA, 6.784(1) \AA$ [33]). A previous study showed that the precipitation of $\mathrm{Nd}(\mathrm{III})$ alone in the same conditions leads to $\mathrm{NdOCl}$ oxychloride formation [13]. The U-Nd2 experiment results show that after $1 \mathrm{~h}$ of wet argon bubbling, the precipitate contains uranium dioxide, $\mathrm{UO}_{2}$, with lattice parameter $\mathrm{a}=5.471(1) \AA$, and only very few $\mathrm{NdOCl}$ traces. These results demonstrate that uranium (III) is more sensitive to the precipitation than neodymium (III) and precipitates first while the neodymium ions are still solubilized in the molten chloride. The consecutive reaction of the two elements explains their separation in two compounds in the precipitate and the non-formation of a solid solution. 


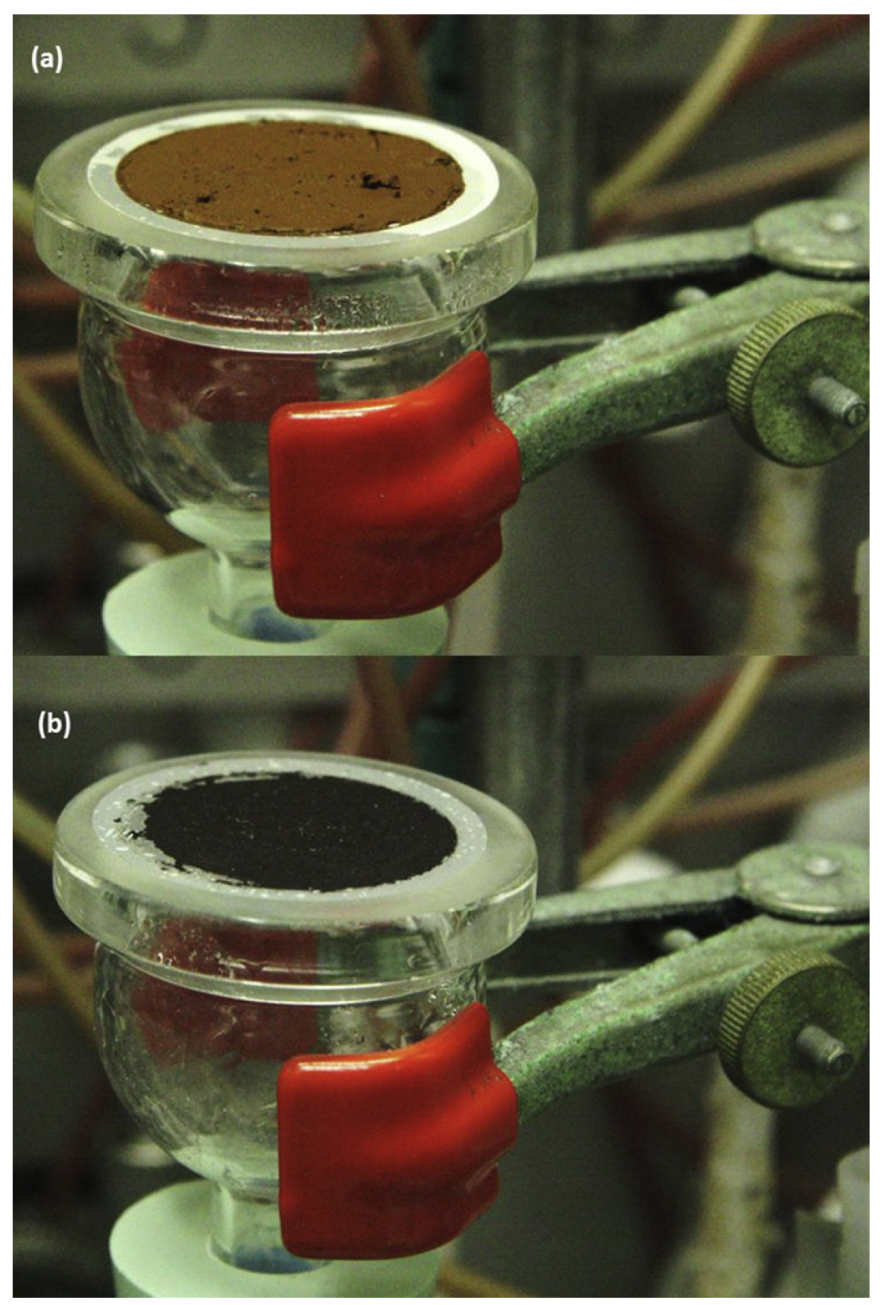

Fig. 9. Picture of uranium precipitate obtained by precipitation of $\mathrm{U}(\mathrm{III})$ in $\mathrm{LiCl}-\mathrm{CaCl}_{2}$ (30-70 mol\%) at $705{ }^{\circ} \mathrm{C}$ using (a) wet argon sparging and (b) wet argon contaminated with oxygen.

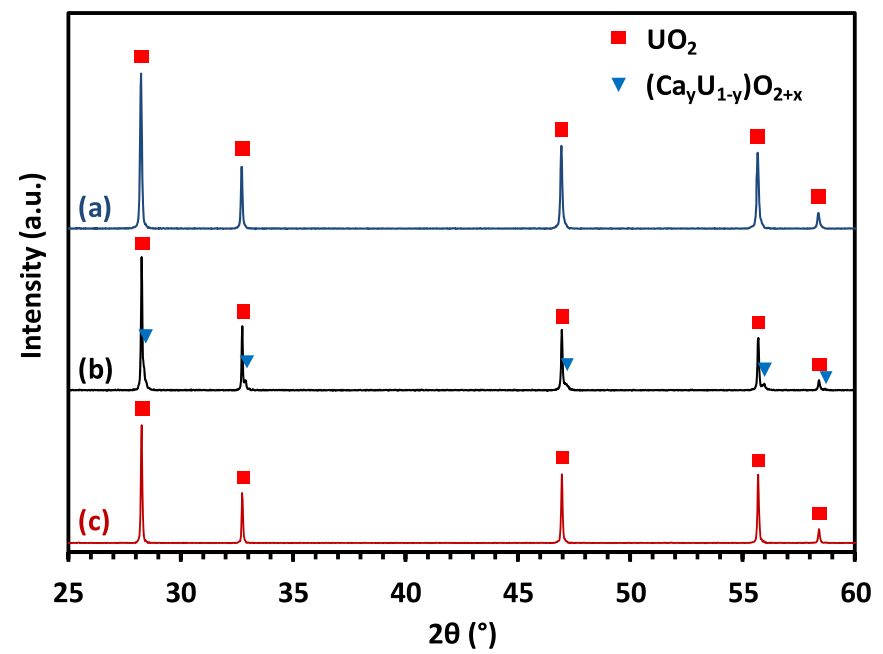

Fig. 10. XRD patterns of precipitate obtained by (a) precipitation of $5 \mathrm{wt} \% \mathrm{U}(\mathrm{III})$ in $\mathrm{LiCl}-$ $\mathrm{CaCl}_{2}$ (30-70 mol\%) at $705{ }^{\circ} \mathrm{C}$ using wet argon sparging, (b) precipitation of $5 \mathrm{wt} \%$ $\mathrm{U}(\mathrm{III})$ in $\mathrm{LiCl}-\mathrm{CaCl}_{2}(30-70 \mathrm{~mol} \%)$ at $705^{\circ} \mathrm{C}$ using wet argon contaminated with oxygen and (c) precipitation of $5 \mathrm{wt} \% \mathrm{U}(\mathrm{III})$ and excess of metallic uranium in $\mathrm{LiCl}-\mathrm{CaCl}_{2}$ (30-70 mol\%) at $705{ }^{\circ} \mathrm{C}$ using wet argon sparging. $\mathrm{UOCl}$ is not observed (main diffraction peaks expected at $25.6^{\circ}$ and $31.4^{\circ}$ ).

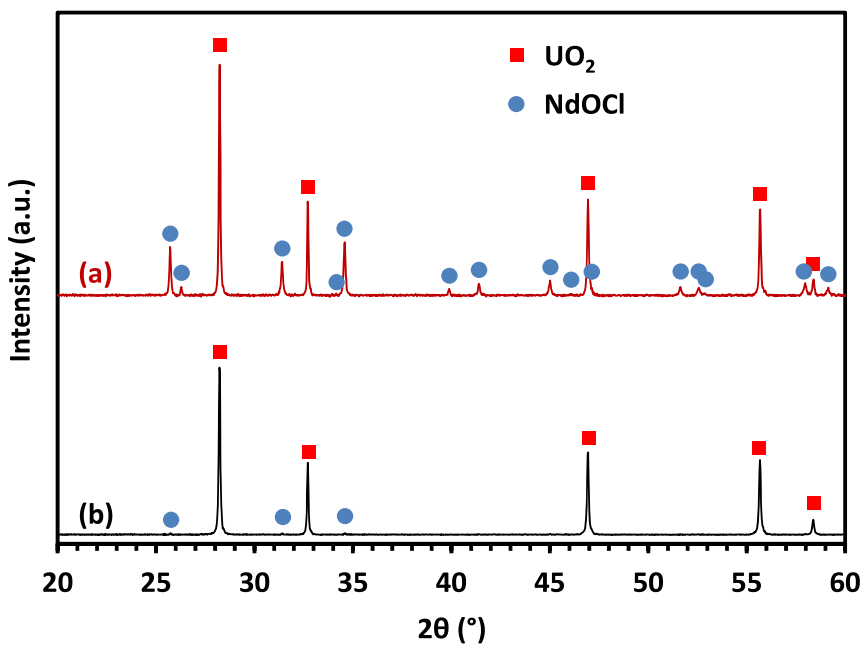

Fig. 11. XRD pattern of uranium and neodymium precipitate obtained by precipitation of $5 \mathrm{wt} \%$ equimolar $\mathrm{U}(\mathrm{III})-\mathrm{Nd}(\mathrm{III})$ in $\mathrm{LiCl}-\mathrm{CaCl}_{2}\left(30-70 \mathrm{~mol} \%\right.$ ) at $705{ }^{\circ} \mathrm{C}$ using wet argon sparging (a) after $6 \mathrm{~h}$ wet argon sparging (complete precipitation of the actinide and lanthanide of the salt) and (b) after $1 \mathrm{~h}$ wet argon sparging (incomplete precipitation).

\section{Conclusion}

The salt $\mathrm{LiCl}-\mathrm{CaCl}_{2}\left(30-70 \mathrm{~mol} \%\right.$ ) at $705{ }^{\circ} \mathrm{C}$ used in this study for uranium(III) precipitation is oxoacid with a water dissociation constant of $10^{-4.0}$. This property leads to a low complexation of solubilized uranium, inducing its partial volatilisation during precipitation. Nevertheless, despite the use of oxoacid salt, the uranium precipitation is quantitative and there is no more solubilized uranium in the molten salt after the end of precipitation by wet argon sparging, corresponding to a conversion rate over $99.9 \%$. $\mathrm{U}(\mathrm{III})$ precipitation leads to a red brown powder of $\mathrm{UO}_{2}$ with a stoichiometric composition $\mathrm{UO}_{2.00}$. This oxide crystallized as truncated cubes in the range of $0.2-2 \mu \mathrm{m}$. The amount of calcium in the precipitate is $1.2 \mathrm{wt} \%$ but no lithium is detected in the powder. The final oxidation state of uranium using wet argon sparging is (IV). Nevertheless, Uranium (III) is very sensitive to the oxidation, giving a second phase in the case of $\mathrm{O}_{2}$ pollution of the wet argon, and inducing a strong increase of calcium contamination in the precipitate. At the opposite, the use of more reductive conditions with metallic uranium leads to a lower calcium contamination and a strong decrease the volatility of uranium by preventing $\mathrm{UCl}_{4}$ formation during precipitation.

Finally, the sensitivity of uranium (III) precipitation was tested in comparison with neodymium (III) in the co-precipitation of the two elements. No solid solution was formed, due to the high precipitation reactivity of uranium leading to the consecutive precipitation of the two elements.

\section{Acknowledgment}

This work was partially supported by the PARIS ("Physico-chimie des Actinides et des Radioéléments aux Interfaces et en Solution") French Research Group included in the PACEN ("Programme sur l'Aval du Cycle et l'Energie Nucléaire") Program. The authors would like to thank Nora Djelal, Laurence Burylo (UCCS, University of Lille) and Thierry Plet (CEA Marcoule) for their technical assistances. We are also thankful to Anne Lélias for the acidity analyses.

\section{References}

[1] H.P. Nawada, K. Fukuda, J. Phys. Chem. Solids 66 (2005) 647-651, http:// dx.doi.org/10.1016/j.jpcs.2004.07.022. 
[2] J. Lacquement, H. Boussier, A. Laplace, O. Conocar, A. Grandjean, J. Fluor. Chem. 130 (2009) 18-21, http://dx.doi.org/10.1016/j.jfluchem.2008.07.011.

[3] O. Conocar, N. Douyere, J. Lacquement, J. Nucl. Mater. 344 (2005) 136-141, http://dx.doi.org/10.1016/j.jnucmat.2005.04.031.

[4] E. Mendes, O. Conocar, A. Laplace, N. Douyère, M. Miguirditchian, Procedia Chem. 7 (2012) 791-797, http://dx.doi.org/10.1016/j.proche.2012.10.120.

[5] L. Martinot, M. Ligot, J. Radioanal, Nucl. Chem. Lett. 136 (1989) 53-60, http:// dx.doi.org/10.1007/bf02165086.

[6] Y.H. Cho, T.-J. Kim, S.E. Bae, Y.J. Park, H.J. Ahn, K. Song, Microchem. J. 96 (2010) 344-347, http://dx.doi.org/10.1016/j.microc.2010.06.001.

[7] Y.H. Kang, S.C. Hwang, H.S. Lee, E.H. Kim, S.W. Park, J.H. Lee, J. Mater. Process Technol. $209 \quad$ (2009) 5008-5013, http://dx.doi.org/10.1016 j.jmatprotec.2009.01.024.

[8] T.-J. Kim, Y. Jung, J.-B. Shim, S.-H. Kim, S. Paek, K.-R. Kim, D.-H. Ahn, H. Lee J. Radioanal. Nucl. Chem. 287 (2011) 347-350, http://dx.doi.org/10.1007/ s10967-010-0689-z.

[9] S.H. Lee, C.H. Cho, Y.S. Lee, H.S. Lee, J.G. Kim, Korean J. Chem. Eng. 27 (2010) 1786-1790, http://dx.doi.org/10.1007/s11814-010-0410-5.

[10] T.R. Griffiths, V.A. Volkovich, J. Nucl. Mater. 274 (1999) 229-251, http:// dx.doi.org/10.1016/S0022-3115(99)00091-4.

[11] A. Laplace, J.F. Vigier, T. Plet, C. Renard, F. Abraham, C. Slim, S. Delpech, G. Picard, Process for preparing an oxychloride and/or oxide of actinide(s) and/or of lanthanide(s) from a medium comprising at least one molten salt, Patent EP2760794. (2014).

[12] W.R. Grimes, J.H. Shaffer, G.M. Watson, Preparation of refractory oxide crystals, Patent US3063795. (1962)

[13] J.F. Vigier, C. Renard, A. Laplace, J. Lacquement, F. Abraham, J. Nucl. Mater. 432 (2013) 407-413, http://dx.doi.org/10.1016/j.jnucmat.2012.08.039.

[14] J.-F. Vigier, C. Renard, N. Henry, A. Laplace, F. Abraham, Inorg. Chem. 51 (2012) 4352-4358, http://dx.doi.org/10.1021/ic3000558.

[15] K.H. Mahendran, S. Nagaraj, R. Sridharan, T. Gnanasekaran, J. Alloys Compd. 325 (2001) 78-83, http://dx.doi.org/10.1016/S0925-8388(01)01387-1.

[16] D.R. Lide, Handbook of Chemistry and Physics $73^{\text {rd }}$ Edition, 1992-1993.

[17] I. Grenthe, J. Drożdżyński, T. Fujino, E.C. Buck, T.E. Albrecht-Schmitt, S.F. Wolf, in: L.R. Morss, N.M. Edelstein, J. Fuger (Eds.), Uranium The Chemistry of the Actinide and Transactinide Elements, Springer Netherlands, 2006, pp.
253-698, http://dx.doi.org/10.1007/978-94-007-0211-0_5.

[18] J. Drozdzynski, Coord. Chem. Rev. 249 (2005) 2351-2373, http://dx.doi.org/ 10.1016/j.ccr.2005.05.016.

[19] C. Caravaca, A. Laplace, J. Vermeulen, J. Lacquement, J. Nucl. Mater. 377 (2008) 340-347, http://dx.doi.org/10.1016/j.jnucmat.2008.01.031.

[20] Y. Castrillejo, M.R. Bermejo, E. Barrado, A.M. MartInez, P. Diaz Arocas, J. Electroanal. Chem. 545 (2003) 141-157, http://dx.doi.org/10.1016/s00220728(03)00092-5.

[21] F.C. Zeisberg, International Critical Tables, Partial Vapor Pressures of Aqueous Solutions of HCl, Vol. III, Vapor Pressure Lowering, 1928, p. 292.

[22] V. Petř́iček, M. Dušek, L. Palatinus, Z. Krist. 229 (2014) 345, http://dx.doi.org/ 10.1515/zkri-2014-1737.

[23] V.L. Cherginets, E.G. Khailova, Electrochim. Acta 39 (1994) 823-829, http:// dx.doi.org/10.1016/0013-4686(94)80031-6.

[24] B. Trémillon, Electrochimie analytique et réaction en solution, Tome 1 (1993).

[25] E. Mendes, O. Conocar, A. Laplace, N. Douyère, J. Lacquement M. Miguirditchian, Actinides oxidative back-extraction from liquid aluminium, in molten chloride media, in: Molten Salts Chemistry and Technology, John Wiley \& Sons, Ltd, 2014, pp. 411-419, http://dx.doi.org/10.1002/ 9781118448847.ch6c.

[26] R. Combes, B. Tremillon, F. Deandrade, M. Lopes, H. Ferreira, Anal. Lett. 15 (1982) 1585-1600, http://dx.doi.org/10.1080/00032718208064449.

[27] D.M. Gruen, R.L. McBeth, J. Inorg. Nucl. Chem. 9 (1959) 290-301, http:// dx.doi.org/10.1016/0022-1902(59)80233-5.

[28] V.A. Volkovich, D.E. Aleksandrov, B.D. Vasin, T.K. Khabibullin, D.S. Mal'tsev, Rasplavy, 2009, pp. 62-68.

[29] G. Leinders, T. Cardinaels, K. Binnemans, M. Verwerft, J. Nucl. Mater. 459 (2015) 135-142, http://dx.doi.org/10.1016/j.jnucmat.2015.01.029.

[30] L. Mazeina, A. Navrotsky, M. Greenblatt, J. Nucl. Mater. 373 (2008) 39-43, http://dx.doi.org/10.1016/j.jnucmat.2007.03.269.

[31] A. Pialoux, B. Touzelin, J. Nucl. Mater. 255 (1998) 14-25, http://dx.doi.org/ 10.1016/s0022-3115(98)00015-4.

[32] T. Ohmichi, S. Fukushima, A. Maeda, H. Watanabe, J. Nucl. Mater. 102 (1981) 40-46, http://dx.doi.org/10.1016/0022-3115(81)90544-4.

[33] G. Meyer, T. Schleid, Z. Anorg. Allg. Chem. 533 (1986) 181-185, http:// dx.doi.org/10.1002/zaac.19865330222. 